\title{
NOX AND VOC MEASUREMENTS AND HEALTH RISK ASSESSMENT IN AN INFORMAL SETTLEMENT IN DURBAN
}

\author{
J. Cookson ${ }^{1}$, A. Royall, R. Diab ${ }^{1}$ and M. Binedell ${ }^{2}$ \\ ${ }^{I}$ School of Environmental Sciences, University of KwaZulu-Natal, Durban \\ ${ }^{2}$ Natural Resources and Environment, CSIR, Durban \\ diab@ukzn.ac.za, aroyal@srk.co.za, stupifyde@yahoo.com
}

\begin{abstract}
A previous study by Muller et al. (2003) investigated $\mathrm{NO}_{x}$, benzene, toluene, ethylbenzene and xylene levels in households in the densely settled informal settlement of Cato Crest located within the Durban Metropolitan area. A Health Risk Assessment based on the United States EPA approach showed that the residents of Cato Crest experienced significant health risks as a result of exposure to these pollutants largely as a result of kerosene usage in their homes. Specifically, the study which was conducted in September 2000 in 14 households, showed that exposure to NOx over a 24-hour period indicated a potential health risk in all the households, that benzene poses a health risk in 50\% of the households, whereas there is no health risk associated with exposure to toluene. A follow-up study was conducted in July 2006 targeting similar households and pollutants to investigate whether comparable results were found in a typical winter period, when air quality is generally expected to deteriorate.
\end{abstract}

\section{Introduction}

Poor indoor air quality has become a public health threat world-wide and a major concern in the domestic environment (Bruce et al., 2000; Hester et al., 1995). A source of indoor air pollution in domestic environments is the partial combustion of high polluting fuels. This is a common cause of indoor air pollution in developing countries, where the use of electricity may be unavailable or too expensive (Bruce et al., 2000; Van Horen, 1996). This is reinforced by the fact that $50 \%$ of people, mainly in the developing areas, resort to cheaper, unhealthy fossil fuels such as coal, wood, dung and kerosene (Bruce et al., 2000).

Pollutants that reside indoors have been associated with pulmonary disease, asthma, tuberculosis, infant and perinatal mortality, low birth weight, cataracts, cancer (such as nasopharyngeal, laryngeal and lung). These symptoms are mainly experienced in people living in developing countries who are exposed to poor air quality at a domestic level (Bruce et al., 2000). According to Bruce et al. (1998) the most common health effects of indoor pollutants are chronic obstructive lung disease (COLD) in adults and acute lower respiratory infection (ALRI) in children.

Kerosene is a type of fuel used by people in developing countries. It is the predominant source of energy in the Cato Crest informal settlement, producing chemicals such as VOCs, nitrogen dioxide and carbon monoxide causing poor indoor air quality and health disorders. (Hounsome et al., 2002). In South Africa, 5-6 million households are reliant on kerosene (Van Horen, 1996).

This study focuses on the informal settlement of Cato Crest in KwaZulu-Natal, Durban. Previous research shows that kerosene is the most common fossil fuel used for cooking and heating in Cato Crest (CMDA, 2001) but it is often used in combination with other fuels depending on the seasons and the prices of the energy sources. This study addresses the emissions of Volatile Organic Compounds and $\mathrm{NO}_{x}$ due to the use of kerosene. It acts as a follow up to a previous study conducted by Muller (2001) in September 2000.

2 Aim and ObjectivesThe aim of this study is to determine the exposure of residents in the Cato Crest informal settlement to VOCs and 
$\mathrm{NO}_{\mathrm{x}}$, using passive air samplers. These data will be used to develop a Health Risk Assessment (HRA).

The specific objectives are:

- To monitor VOCs, including benzene, toluene, ethylbenzene and xylene (BTEX) and nitrogen dioxide $\left(\mathrm{NO}_{\mathrm{x}}\right)$ in households during a winter period using passive air samplers

- To determine exposure of residents to VOCs and $\mathrm{NO}_{x}$

- To undertake a HRA to determine health risks

- To compare the results of the study with results of a previous study conducted in September 2000

\section{Identification of households}

As this study is a follow-up of a previous project, it was preferable to monitor air quality in the same households. However certain limiting factors made this goal unfeasible. The informal settlement is dynamic and variable in nature and therefore many of the units had moved or been replaced. Certain residents who had participated in the previous study were not willing to participate, as they did not benefit from the earlier investigation, therefore their households were not monitored. The exact units that were sampled previously were also difficult to locate as there are no street names and the house numbers are highly disorganised and difficult to discern in many cases.

\section{Passive Samplers}

This project used Radiello Passive Air Samplers, supplied by Envirocon, Johannesburg. The badge comprises a diffusive body, absorbing cartridge secured in a glass container with a polycarbonate screw-thread cap and a supporting plate. To assemble the badge, the researcher needs to remove the cartridge from the airtight container and insert it into the diffusive body then mount it on a supporting plate (Radiello, 2003)

\section{Health Risk Assessment}

The study was conducted using the Environmental Protection Agency Health Risk Assessment model (EPA HRA), which is used to evaluate adverse health effects caused by a certain pollutant, substance or chemical, using empirical data (Matooane, M., 2005, pers. comm.). The National Academy of Sciences (NAS) first introduced the Health Risk Assessment framework in 1983. The National Research Council (NRC) revised it in 1994, developing a framework involving four steps, namely Hazard Identification, Exposure Assessment, Dose-response Assessment and Risk Characterization (EPA, 1991a).

\subsection{Hazard Identification}

The first phase of the HRA framework is known as Hazard Identification. This involves the recognition of dangerous chemicals or set of circumstances, which could potentially cause adverse health implications. It also involves defining the characteristics of the hazardous chemical (Whyte, 1980).

The dangerous chemical under investigation is kerosene. It is a cheap fuel source for cooking, heating and lighting, which is utilized by $70 \%$ of households in low-income metropolitan regions. Approximately 5 million households in South Africa are reliant on kerosene. Of the total kerosene usage $21 \%$ is used for cooking, $14 \%$ is used for heating and $13 \%$ is utilized to produce lighting (Muller, 2001).

\subsection{Exposure Assessment}

Exposure Assessment makes up the second step, where the exposed population is identified. The duration, pathway, frequency and intensity of exposure is investigated, while the population parameters (characteristics and behaviour) are also considered (NRC, 1994). The risk depends on the nature of the toxicant and the degree of exposure (Dawson, et. al., 1991). Exposure assessment is determined by conducting field experiments regarding the pollutant and estimating human exposure periods (Guy, 2000). The exposure 
duration is determined using the following equation (EPA, 1991c)

$$
\mathrm{ED}=\mathrm{ET} \times \mathrm{EF} \times \mathrm{DE}
$$

(equation 6.1)

Where,

ET is the Exposure Time in hours/day

$\mathrm{EF}$ is the Exposure Frequency in days/year

$\mathrm{DE}$ is the Duration of Exposure (in years)

The Exposure Assessment is used in the determination of the Acute Hourly Dose (AHD), which is achieved using the following acute exposure rate equation for a non-carcinogenic compound (EPA, 1991c),

$\mathrm{AHD}=\underline{\mathrm{C} \times \mathbb{R}}$

(equation 6.2)

BW

Where $\mathrm{C}$ is the concentration of the pollutant in $\mu \mathrm{gm}^{-3}$

IR is the inhalation rate in $\mathrm{m}^{3} / \mathrm{h}$

$\mathrm{BW}$ is the mean body weight in $\mathrm{kg}$.

In order to determine the Average Daily Dose, the following chronic exposure rate equation for a noncarcinogenic compound is used (EPA, 1991c),

$\mathrm{ADD}=\underline{\mathrm{C} \times \mathrm{IR} \times \mathrm{ED}}$

BW x AT

(equation 6.3)

Where ADD is the lifetime average daily dose measured in $\mu \mathrm{g} / \mathrm{kg} /$ day

$\mathrm{C}$ equates to the concentration of the pollutant in $\mu \mathrm{gm}^{-3}$

IR is the inhalation rate in $\mathrm{m}^{3} /$ day

ED is the exposure duration (the number of days that the receptors are exposed to the chemical)

$\mathrm{BW}$ is the mean body weight in $\mathrm{kg}$

$\mathrm{AT}$ is the average time period of exposure in days.

To determine the exposure dose of a carcinogenic compound a similar equation is used, where ADD is replaced by LADD (Lifetime Average Daily Dose), which is also measured in $\mu \mathrm{g} / \mathrm{kg} /$ day (Muller, 2001). The equation that is used to calculate the LADD is as follows,

$$
\mathrm{LADD}=\frac{\mathrm{C} \times \mathrm{IR} \times \mathrm{ED}}{\mathrm{BW} \times \mathrm{AT}}
$$

\subsection{Dose-Response Assessment}

The third step is the Dose-Response Assessment, which develops a relationship between the dosage of the pollutant and the adverse health effects experienced by an individual. This depends on the frequency, duration, and level of exposure and susceptibility of the receptor, which is determined by age, eating habits, type of employment, socioeconomic characteristics and health status (NRC, 1994).

Benchmark values represent the threshold, above which adverse health effects would be experienced and below which no adverse symptoms would develop. These values are known as a Reference Concentration or Reference Dose (RfC/RfD) (EPA, 1997). For example the Californian Environmental Protection Agency has developed benchmark values known as Reference exposure levels (RELs) (OEHHA, 2005). The ATSDR has developed minimum reference levels (MRL), which indicate the daily human exposure to dangerous chemicals that will not be associated with appreciable risk of developing adverse non-cancer effects (ATSDR, 2005b).

\subsection{Risk Characterisation}

The final step, Risk Characterisation, integrates the results from the first three steps to record the type and potential frequency of the adverse health implications in the form of the Hazard Quotient (HQ) (NRC, 1994). This value reveals whether there is a presence or absence of associated health implications and is used to determine non-cancer risks. If the $\mathrm{HQ}$ is above 1, there is a risk to sensitive receptors that associated health problems are likely to occur, and if it is below 1, symptoms are unlikely to develop. The higher the HQ, the greater the risk (NRC, 1994). 
In order to determine the $\mathrm{HQ}$, which is a dimensionless value, for chronic exposure, the following calculation is required (NRC, 1994):

$\mathrm{HQ}=\underline{\mathrm{ADD}}$

$$
\text { DRV (equation 6.5) }
$$

To determine acute exposure ADD is replaced by AHD. DRV represents the Dose Response Value, such as the Reference Concentration (RfC) or Minimum Reference Level (MRL) that represents the benchmark concentration of the contaminant. Below this concentration adverse implications are unlikely to result in the exposed population after acute or chronic exposure. This state will exist until the threshold is reached, after which deleterious effects are probable to occur. Different $\mathrm{RfC}$ values have been produced by different agencies, such as the ATSDR (Agency for Toxic Substances and Disease Registry) (Muller, et. al., 2003).

Cancer risks are expressed as a probability depending on exposure (Muller, 2001). The cancer risk is calculated using the following equation, where IUR is the Inhalation Unit Risk.

\section{Cancer risk $=$ LADD $\times$ IUR $\quad$ (equation 6.6)}

Scientists have assumed that there is no safe exposure level to a carcinogen and even a very low dosage can result in the development of cancerous tumours (EPA, 1991a).

\section{Results}

The results of the study are presented in table $6.1-$ 6.3 .

Table 6.1 Benzene Results and Comparison

\begin{tabular}{|l|l|l|}
\hline & Range $\left(\mu \mathrm{g} / \mathrm{m}^{3}\right)$ & Mean $\left(\mu \mathrm{g} / \mathrm{m}^{3}\right)$ \\
\hline $\begin{array}{l}\text { 24-hour Concentration (2006 } \\
\text { study) }\end{array}$ & $3.5-45.05$ & 14.98 \\
\hline $\begin{array}{l}\text { South Durban Health Study- } \\
\text { ambient air }\end{array}$ & $1.5-8.6$ & 6.4 \\
\hline Previous study (2000 study) & $31.11-1644.44$ & 680.71 \\
\hline
\end{tabular}

As presented above, the results of the previous study (September 2000) are substantially higher than the results of the 2006 study. The significant difference exhibited between the two studies (September 2000 and July 2006) may be due to the fact that different passive sampling techniques and different households were used. The samplers were not fixed therefore it is possible that there was interference by the residents. The Benzene and Toluene results were compared to the South Durban Health Study. The results are comparable and relatively similar.

\section{Recommendations and Conclusion}

The results of this assessment have been used to draw up recommendations, which are as follows:

- Increase the sample size;

- Determine the most suitable passive sampling system;

- Conduct a corresponding social survey and

- Provide an in depth explanation of the study and samplers to the residents.

The September 2000 study revealed that the residents of Cato Crest experienced potential health risks as a result of $\mathrm{NO}_{x}$ and Benzene exposure and that the US EPA default exposure factors differ considerably to those applicable to an informal settlement in South Africa. It was concluded that the July 2006 pilot study results are inconclusive and further investigation is needed.

\section{Reference}

ATSDR. (2005b). Minimal Risk Levels (MRLs) for Hazardous Substances, http://www.atsdr.cdc.gov/ mrls.html, Accessed 25.08.06. 
Table 6.2 Toluene Results and Comparison

\begin{tabular}{|l|l|l|}
\hline & Range $\left(\mu \mathrm{g} / \mathrm{m}^{3}\right)$ & Mean $\left(\mu \mathrm{g} / \mathrm{m}^{3}\right)$ \\
\hline $\begin{array}{l}\text { 24-hour Concentration (2006 } \\
\text { study) }\end{array}$ & $1.86-9.3$ & 4.43 \\
\hline $\begin{array}{l}\text { South Durban Health Study } \\
\text { ambient air }\end{array}$ & $5.4-37.6$ & 26.6 \\
\hline Previous study (2000 study) & $514-3056$ & 1617.86 \\
\hline
\end{tabular}

Table 6.3 Nitrogen Dioxide Results and Comparison

\begin{tabular}{|l|l|l|}
\hline & Range $\left(\mu \mathrm{g} / \mathrm{m}^{3}\right)$ & Mean $\left(\mu \mathrm{g} / \mathrm{m}^{3}\right)$ \\
\hline $\begin{array}{l}\text { 24-hour Concentration (2006 } \\
\text { study) }\end{array}$ & $33.86-54.56$ & 49.5 \\
\hline Previous study (2000 study) & $51.8-103.9$ & 1605.5 \\
\hline
\end{tabular}

Bruce, N., Perez-Padilla, R. and Albalak, R. (2000). Indoor air pollution in developing countries: a major environmental and public health challenge, Bulletin of the World Health Organisation, 78 (9).

Bruce, N., Neufeld, L., Boy, E. and West, C. (1998). Indoor biofuel air pollution and respiratory health: the role of confounding factors among women in highland Guatemala, International Journal of Epidemiology, 27 (3), 454-458.

CMDA. (2001). Community Profile for the Cato Manor Area, Cato Manor Development Association, Durban.

Dawson, J., Morgan, D., Lamont, T., Dayon, A. and Elwood, P. (1991). Hazardous Waste and Human Health, Oxford University Press, New York.

EPA. (1991a). Risk Assessment for Toxic Air Pollutants: A Citizen's Guide, http://www.epa.gov/ ttn/atw/3_90_024.html, Accessed 23.08.06.

EPA. (1991c). Human Health Evaluation Manual, http://www.epa.gov/oswer/riskassessment/pdf/ defaultExposureParams.pdf, Accessed 25.08.06.

EPA. (1997). Exposure Factors Handbook, http:// www.epa.gov/ncea/efh/, Accessed 25.08.06.
Hester, R.E. and Harrison, R.M. (1995). Volatile Organic Compounds in the Atmosphere, The Royal Society of Chemistry, United Kingdom.

Hounsome, R., Binedell, M., Madonsela, V., Napier, M., Hansson, C. and Ahman, M. (2002). Lead Programme in Technologies for Enhanced Environmental Management : Sustainable Development in Poor Urban Communities, Pretoria, South Africa.

Matooane, M. (2005). Personal Communication, Quantitative Human Health Risk Assessment, CSIR.

Muller, E., Diab, R.D., Binedell, M. and Hounsome, R. (2003). Health Risk Assessment of kerosene usage in an informal settlement in Durban, South Africa, Atmospheric Environment, 37, 20152022.

Muller, E.A. (2001). Quantification of the Human Health Risks associated with kerosene use in the informal settlement of Cato Manor, Durban, Unpublished M.Sc Dissertation, University of KwaZulu Natal, Durban.

NRC (National Research Council). (1994). Science and Judgement in Risk Assessment, National 
Academy Press, USA.

OEHHA. (2005). Air Chronic RELs, http:// www.oehha.ac.za.gov/air/chronic_rels/ AllChrels.html, Accessed 19.08.06.

Radiello. (2003). Radiello badges, http:// www.radiello.com/english/full_en.htm, Accessed 23.03.06.

Whyte, A.V. and Burton, I. (1980). Environmental Risk Assessment, John Wiley \& Sons, USA.

Van Horen, C. (1996). Indoor air Pollution from coal and wood use in South Africa: an overview, Energy for Sustainable Development, 3 (1). 